\title{
EREBEA
}

Revista de Humanidades

y Ciencias Sociales

Núm. 5 (2015), pp. 9-18

ISSN: 0214-0691

\section{La Exégesis del Evangelio de Juan en Heracleón y ORÍGENES: NUEVAS LÍNEAS DE INVESTIGACIÓN ACERCA DE UNA CUESTIÓN CONTROVERTIDA}

\section{Patricia Andrea Ciner \\ Universidad Nacional de San Juan- Universidad Católica de Cuyo}

\section{RESUMEN}

El trabajo intenta mostrar cómo los dos primeros comentarios realizados al Evangelio de Juan en el período patrístico, el de Heracleón y el de Orígenes, responden a dos posibilidades igualmente válidas de interpretación y que las grandes líneas de exégesis de la posterior teología occidental se formaron en este tipo de "ambigüedad inicial”.

Palabras Clave

Evangelio de Juan; Heracleón; Orígenes; Exégesis.
Abstract

This article shows how the first two commentaries in the patristic period on the Gospel According to John, those of Heracleon and Origen, drew on two equally valid interpretative possibilities. The article also shows that the large lines of subsequent theological interpretation in the West develop from this type of initial ambiguity.

\section{KeYwords \\ Gospel According to John; Heracleon;} Origen; exegesis. 



\section{I-INTRODUCCIÓN}

Sin temor a equivocarnos, podemos iniciar este artículo diciendo que el Evangelio de Juan escrito hace 2000 años, continúa presentando increíbles desafíos a los estudios patrísticos contemporáneos. Esto se debe a que en este texto se evidencia una realidad insoslayable del cristianismo de los primeros siglos: la existencia de una diversidad de corrientes acerca de la identidad de Jesús. También muestra que estas diferentes corrientes son absolutamente válidas y que en el caso particular del análisis que realizaremos a continuación, las respectivas exégesis de Heracleón y Orígenes son coherentes y legítimas y nos obligan a comprenderlas y valorarlas en toda su complejidad. Tal como lo afirmara el reconocido especialista en temas joaninos Raimond Brown,el Evangelio de Juan debe ser considerado como el texto más audaz del Nuevo Testamento ${ }^{1}$.También A. Harnack observó que este evangelio era uno de los mayores enigmas de la primitiva historia del cristianismo y C. Dodd, por su parte, escribió que "si consiguiéramos entender a Juan, habríamos comprendido qué era realmente el primitivo cristianismo ${ }^{2 "}$. Es posible agregar además que es en este evangelio,donde se puede encontrar la historia posterior de todos los conflictos teológicos y metafísicos de Occidente con respecto a la identidad de Jesús y a su verdadera obra espiritual.Esta afirmación cobra sentido cuando se recuerda que fue el valentiniano Heracleón quien realizó la primera exégesis de este Evangelio y luego fue Orígenes quien escribió el segundo gran comentario, citando allí los fragmentos que se conocen del maestro gnóstico. Esto evidentemente fue posible debido a que el texto mismo del Evangelio de Juan permitía las dos exégesis. Justamente la pregunta que guiará este artículo será la siguiente: ¿̨por qué el texto del Evangelio de Juan hizo posible dos exégesis tan diferentes? Para responderla, iremos desglosando los diversos elementos de la pregunta, a fin de evidenciar que la respuesta que obtendremos, necesariamente deberá tener múltiples perspectivas de análisis. Nuestra metodología de trabajo seguirá un rumbo, que creemos, no ha sido demasiado transitado: mostrar a partir del texto griego del Comentario al Evangelio de Juan, cómo las dos exégesis son absolutamente coherentes y legitimas. Sabemos que esta metodología cuenta con problemas importantes. La primera y más evidente es la escasa cantidad de fragmentos de Heracleón, comparados con las extensas explicaciones de

1 R. Brown, La Comunidad del Discipulo Amado, Salamanca, 2006, prefacio.

2 Op. cit, prefacio. 
Orígenes.Sin embargo, pensamos que esta empresa es posible, debido a que Orígenes posee una cualidad que lo ha distinguido siempre entre los grandes teólogos: nos referimos a su inmensa honestidad intelectual. Esto nos permitirá ir distinguiendo con meridiana claridad, cuáles eran los supuestos teológicos y también las variantes en los manuscritos en los que apoyaba su exégesis Heracleón y cuál era la propia posición del alejandrino.En ese sentido, nuestra reflexión se detendrá en las siguientes cuestiones:

A. El autor del Evangelio de Juan:la controvertida cuestión de la comunidad joánica

B. El texto del Evangelio de Juan: la existencia de diversos manuscritos

C. Ejemplos de variantes textuales en el Comentario del Evangelio de Juan

A. El autor del Evangelio de Juan: la controvertida cuestión de la COMUNIDAD JOÁNICA

Es evidente que la cuestión más difícil de resolver y para la que lamentablemente no tenemos una respuesta nítida es la cuestión referida a la "llamada comunidad joánica”. Dos son las preguntas que esta comunidad plantea: ¿̇hubo un momento en que ambos grupos, que posteriormente se denominarían gnósticos y protoortodoxos ${ }^{3}$, convivieron juntos? ¿existió en algún momento un texto también único del Evangelio de Juan? A la primera pregunta y más allá de todas especulaciones que se han realizado hasta el momento, contestaremos que sí. La prueba de esta convivencia transitoria estaría dada justamente en el enigmático cisma intra-juánico que se relata en $1 \mathrm{Jn}(2,18-19)$. Sólo por que alguna vez habían estado juntos los dos grupos, el escritor del la primera Carta de Juan, podía lamentarse de esta forma:

"Hijos míos es la última hora. Habéis oído que iba a venir un AntiCristo. Pues bien, muchos anticristos han aparecido, por lo cual nos damos cuenta que ya es la última hora. Salieron de entre nosotros, pero no eran de los nuestros. Si hubiesen sido de los nuestros, habrían permanecido con nosotros"

Creemos que R. Brown en su ya clásico libro La comunidad del discípulo amado, ha dado una respuesta equilibrada a esta difícil cuestión al afirmar que:

"La cuarta fase vio la disolución de los dos grupos después que se escribieron las cartas. Los secesionistas, que ya no estaban en comunión

3 Tomamos esta terminología y su significación correspondiente de los siguientes especialistas: Barth Ehrman, Larry Hurtado y Francisco García Bazán. 
con el ala más conservadora de la comunidad juánica, probablemente pronto se orientaron en el siglo II hacia el docetismo, el gnosticismo, el cerentianismo y el montanismo.Esto explica por qué el cuarto evangelio que ellos llevaron consigo, se halla citado por los escritores heterodoxos antes y con mayor frecuencia que por los ortodoxos"

También quisierámos mencionar la reciente tesis doctoral de W. Pinner acerca de la Reception of the fourth Gospel in the Second Century ${ }^{5}$, para quien también hubo una suerte de "convivencia inicial" entre estos grupos que luego tomaron rumbos teológicos muy diferentes. Sin embargo esta comunidad inicial, habría dejado sus huellas en algunos puntos que Heracleón y Orígenes comparten con respecto a las características que los perfectos y los pneumáticos poseen: ambos han trascendido el mundo de lo manifestado y adoran al Logos de un modo mucho más contemplativo.Esto implicaría un significado común en cuánto a que el Evangelio de Juan estaba destinado sólo a los seres más evolucionados espiritualmente.Por supuesto, que en otros aspectos las diferencias son enormes (la más importante es que para Heracleón existen tres categorías ontológicas separadas: pneumáticos, psíquicos e hílicos) de las cuáles son puede salvarse los pneumáticos y que en cambio para Orígenes la salvación es una posibilidad universal de todas las criaturas espirituales desde la preexistencia.

Con respecto a la existencia de un texto único, esto es también casi imposible de afirmar o de negar categóricamente. Sin embargo nuestra opinión se inclina a que sí hubo un texto originario del Evangelio de Juan. Nos apoyaremos en un testimonio proveniente del mundo pagano y que no siempre ha sido lo suficientemente valorado. Nos referimos a un fragmento de Celso citado por Orígenes:

"Después de esto dice que, algunos creyentes, como si hubieran estado bebiendo, llegan al punto de oponerse a sí mismos y alterar el texto original tres o cuatro o varias veces más y cambian su carácter para poder negar las dificultades que les plantea la crítica" ${ }^{\prime \prime}$.

Pero lo que no estamos en condiciones de responder es por qué este texto único, tuvo diferencias tan importantes en los manuscritos posteriores. Por supuesto, conocemos algunas respuestas dadas con respecto a que los ortodoxos habrían corrompido o deformado el texto original y que este habría sido conservado sólo por los gnósticos: así por ejemplo lo han sostenido Bauer, Ehrman, etc. Sin embargo y a la luz de algunos aspectos referidos al texto griego del Comentario al Evangelio de Juan, podremos ver que la cuestión no tiene una respuesta

4 R. Brown, La comunidad del discipulo amado, Salamanca, 2005, p. 22.

5 W. Pinner,Reception of the fourth Gospel in the Second Century, Athens, Georgia,2010.

6 CC II,27 
tan simplista. Creemos más bien que el hipotético manuscrito original sufrió transformaciones en algunos casos accidentales y en otras intencionales,derivadas de los presupuestos filosóficos y teológicos de ambos grupos.

B. El texto del Evangelio de Juan: la existencia de diversos manuscritos En general la mayoría de los especialistas contemporáneos ha sostenido que, la posición de Orígenes en contra de las afirmaciones de Heracleón, ha dependido exclusivamente de las líneas filosóficas, teológicas y místicas en las que el maestro alejandrino apoyaba su doctrina ${ }^{7}$.Sin desmerecer para nada esta línea de investigación especialmente entre los origenistas, nuestro trabajo intentará mostrar que es necesario tener en cuenta otro factor decisivo para obtener una visión clara del problema. Nos referimos específicamente a la existencia de diferentes manuscritos desde los cuáles, tanto Heracleón como Orígenes, leían y hacían su exégesis del Evangelio de Juan.Seguiremos en nuestro análisis algunas de la tesis del controvertido especialista estadounidense Bart Ehram, quien ha afirmado que :

"Scholars have always recognized this "reactionary" character of Origen's work. What they have not recognized is the degree to which Origen's disagreements with Heracleon relate not simply to varying theological assumptions about the text, but to divergent forms of the text itself. Indeed, a number of their exegetical differences relate closely to their use of variant textual traditions: to some degree, their exegesis of John differs because the wording of their Johannine texts differs."

Si bien compartimos en algunos aspectos esta postura, en otros no la seguiremos totalmente, razón por la cual realizaremos nuestra propia evaluación del problema. Para ello, ampliaremos la cuestión haciendo una breve síntesis acerca de la fecha de consolidación definitiva del texto del Evangelio de Juan. Por supuesto, no pretendemos de ninguna manera agotar el tema de las etapas, autores y fechas de composición del Evangelio de Juan. Sería una tarea destinada al fracaso, tanto por la inmensa bibliografía existente, como por la complejidad misma del problema. Simplemente y a la luz de la tarea que hemos realizado en la traducción del Comentario al Evangelio de Juan ${ }^{9}$, quisiéramos llamar la atención sobre la opinión sostenida por un especialista tan renombrado como Larry Hurtado, acerca de que la redacción final de este evangelio habría sido concluida

7 Cf. A. Castellano, La Exégesis de Origenes y de Heracleón a los Testimonios del Bautista,Chile, 1998.

8 Bart D. Ehrman, Studiesin the Textual Criticism of the New Testament, Leiden-Boston, 2006,p. 269

9 La primera traducción al castellano de este texto, está siendo preparada por la autora de este artículo y será publicada por Ciudad Nueva. 
hacia fines del año $100 .{ }^{10}$ Nuestra posición se basa en los datos que Orígenes proporciona en su Comentario, según los cuáles hasta el siglo III circularon manuscritos con variantes importantes.

También quisiéramos mencionar que Orígenes era plenamente consciente de la existencia de diversidad de manuscritos y los problemas que esto implicaba. Y así lo afirmaba en su Comentario al Evangelio de Mateo:

Las diferencias entre los manuscritos se han vuelto muy grandes, ya sea por negligencia de algunos copistas o por la audacia perversa de otros; o bien se despreocupan de comprobar lo que han transcrito, o bien, al realizar la comprobación, añaden u omiten según les place ${ }^{11}$.

\section{Ejemplos de variantes textuales en el Comentario del Evangelio de JUAN}

Los ejemplos que hemos elegido (podríamos haber elegido muchos más) se refieren a dos tipos de cuestiones:

a- En algunos casos, Orígenes menciona explícitamente las formas gramaticales distintas que ambos autores utilizaban.

b- En otros casos, Orígenes se sorprende de que Heracleón haga una exégesis de un texto que no existe en los manuscritos que él utiliza.

Veamos entonces, dos ejemplos del primer tipo:

En el libro VI y en relación a los testimonios dados por Juan el Bautista, acerca de la pregunta de los fariseos sobre su identidad, Orígenes afirma:

En cuanto a estas palabras 'en el medio de vosotros hay alguien que no conocéis', es necesario definirlas en relación al hijo de Dios, al Logos por quien todas las cosas fueron, que subsiste en su esencia como sujeto y que es idéntico a la Sabiduría. Porque él penetra a través de toda la creación, a fin de que siempre los seres por devenir devengan por él y que de toda cosa, cualquiera que sea, sea siempre verdadero decir: 'Todo fue por él y sin él nada fue' y 'Tú has hecho todo en tu sabiduría.' Si él penetra toda la creación, él penetra evidentemente también a aquellos que preguntan: '¿por qué entonces tú bautizas si no eres ni el Cristo, ni Elías ni el profeta?'. El está en el medio, él que es la palabra misma, la Palabra firme, en todo afirmada por el Padre. ${ }^{12}$

10 L. Hurtado, Señor Jesus Cristo. La devoción a Jesús en el cristianismo primitivo, Salamanca, p. 404

$11 C M t 15,14$

12 CIo VI,XXXVIII, 188. 
$\mathrm{Al}$ referirse a la exégesis del gnóstico, Orígenes escribe:

Heracleón en cambio explica la expresión él está en el medio de vosotros ${ }^{13}$ por él ya está presente, él está en el mundo y entre los hombres, él es manifiesto para todos vosotros. Con esto él refuta nuestra suposición sobre la penetración del mundo entero [del Logos]. Es necesario entonces responderle: ¡¿cuándo no está presente? ¡cuándo no está en el mundo? ${ }^{14}$.

Ha llamado la atención a los especialistas que en la transcripción del versículo

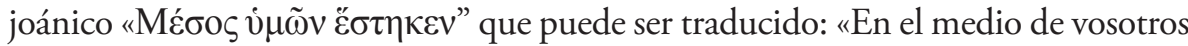
está", Orígenes ha usado el perfecto del verbo "í $\tau \tau \eta \mu$ y no el presente $\sigma \tau \eta \dot{\kappa \varepsilon l}{ }^{15}$. Muy llamativo es que en otros textos como el Contra Celso (II 9,V,2), sí había usado el presente $\sigma \tau \eta ́ \kappa \varepsilon$. Evidentemente la única razón de este cambio era enfatizar la duración continúa que da el tiempo perfecto, para remarcar así la doctrina universal de la presencia del $\Lambda$ ó $\gamma$ os en el cosmos en contra de la posición de Heracleón, que sí usaba el presente para indicar una presencia sólo momentánea del Cristo. En efecto, si bien para los dos teólogos, el Bautista era inferior al Cristo, la interpretación de esta inferioridad era totalmente distinta. Heracleón lo entendía como una confesión de inferioridad del Demiurgo del Antiguo Testamento en relación al Cristo, mientras que Orígenes rechazaba esta concepción sosteniendo que el Bautista era el puente de unión entre las dos Alianzas. Esta controversia y la evidente existencia de dos variantes en la redacción del Evangelio, tendrá importantes consecuencias cosmológicas, soteriológicas y místicas, ya que para el gnóstico a partir de la separación de los dos mundos: el pleromático y el extrapleromático, el Salvador sólo se encontrará temporalmente en el mundo de los psíquicos. Su única misión será fundamentalmente rescatar a los gnósticos, con lo cual se pondrá de manifiesto la doctrina de las tres naturalezas de seres humanos. Para Orígenes por el contrario, la presencia permanente del Logos en el mundo inteligible y en el cosmos creado, tendrá como consecuencia soteriológica más importante que todos los seres a partir de un progreso de purificación espiritual, podrán reconocer la presencia del Logos entendido primero como Jesús Cristo encarnado y luego como Logos-Sabiduría.

El segundo ejemplo está referido al lugar en que Juan bautizaba. La primera sorpresa que el lector encuentra en la versión del texto griego del Evangelio de Juan que Orígenes utiliza,es que Juan bautizaba en un lugar llamado Bethabara y no en Betania, como lo enseña la tradición que hasta hoy se conserva. Heracleón en cambio habría sostenido que esto sucedió en Betania.En efecto, Orígenes afirma lo siguiente:

13 Jn 1,26

14 CIo, VI, XXXIX, 194.

15 Cf. notas 46 y 47 de E. Corsini (Libro VI CIo, p.346) 
Nosotros no ignoramos que en casi todos los manuscritos se encuentra: "Esto pasó en Betania” y que parece que esta lección es bastante antigua. Al menos nosotros hemos leído también "Betania" en Heracleón. Sin embargo yendo a los lugares en la búsqueda de las huellas de Jesús, de sus discípulos y de los profetas, nosotros nos hemos persuadido que no es necesario leer "Betania" sino "Bethabara ${ }^{16}$.

Las razones en las cuáles Orígenes fundamenta su opción textual se fundamentan en sólidos criterios geográficos y etimológicos. En efecto, para el alejandrino Bethabara debía entenderse como "casa de preparación" y en cambio Betania como "casa de obediencia".

Finalmente y para terminar, mostraremos dos casos en que Orígenes se sorprende de que Heracleón haga una exégesis a partir de textos que no existen en los manuscritos que él utiliza. Los dos ejemplos están tomados del libro XIII. En el primero, Orígenes sostiene que:

Pero no sé cómo Heracleón, sobre el pasaje "Dame de este agua", interpretando sobre lo que no está escrito, sostiene que [la Samaritana], apenas estimulada por el Logos, comenzó a odiar desde ese momento el lugar de aquella agua llamada viva ${ }^{17}$.

El segundo es particularmente interesante, porque haría alusión a una versión absolutamente desconocida del Evangelio de Juan, ya que la lección "seis maridos" no está atestiguada por ningún manuscrito conocido.En efecto, en este fragmento se afirma que:

Pues bien, mientras que nosotros leemos: Has tenido cinco maridos ${ }^{18}$, en cambio en Heracleón encontramos: Has tenido seis maridos. Y él lo interpreta así: los seis maridos indican todo el mal material en la que estaba implicada al vivir en prostitución contrariamente al Logos, siendo luego maltratada, despreciada y abandonada por ellos ${ }^{19}$.

La explicación de Orígenes acerca de los argumentos desde los cuales Heracleón sustenta su posición, evidencian una gran coherencia interna, por lo cual se podría pensar que el gnóstico utilizaba también en estos casos, otra versión diferente a la del maestro alejandrino.

16 CIo, VI, XI, 67.

17 CIo, XIII, XI, 65.

18 Jn 4,18

19 CIo, XIII, XI, 71. 


\section{Conclusiones}

Orígenes no pareció sorprenderse en su trabajo sobre el Comentario al Evangelio de Juan, acerca de la existencia de diversos manuscritos y de la necesidad del estudio detallado de los mismos. Sin embargo, la investigación contemporánea pareció olvidarse de este dato tan obvio y centró el problema sólo en las discusiones filosóficas y teológicas. Nuevamente y a casi 2000 ańos de la vida del gran alejandrino, nos vemos en la necesidad de volver al estudio pormenorizado de los manuscritos, para poder así comprender los problemas desde todas sus perspectivas. 